\title{
ER $\beta$-Selective Estrogen Receptor Modulators Produce Antianxiety Behavior when Administered Systemically to Ovariectomized Rats
}

\author{
Alicia A Walf' and Cheryl A Frye ${ }^{*, 1,2,3}$ \\ 'Department of Psychology, The University at Albany-SUNY, Albany, NY, USA; ${ }^{2}$ Department of Biological Sciences, The University at \\ Albany-SUNY, Albany, NY, USA; ${ }^{3}$ The Center for Neuroscience Research, The University at Albany-SUNY, Albany, NY, USA
}

\begin{abstract}
$17 \beta$-Estradiol $\left(E_{2}\right)$ may influence anxiety behavior; however, its effects and mechanisms are not well understood. To determine whether $E_{2}$ 's effects on anxiety behavior may involve actions at intracellular estrogen receptor (ER) $\alpha$ or $\beta$ isoforms, selective ER modulators (SERMs) were administered ( $10 \mu$ g; s.c.) to ovariectomized rats $48 \mathrm{~h}$ before testing for anxiety behavior. Rats received sesame oil vehicle, $17 \beta$ - $E_{2}$, which has a high affinity for $\mathrm{ER} \alpha$ and $\mathrm{ER} \beta$, or SERMs that vary in their activity at ER $\alpha$ and $\beta$. ER $\alpha$-selective SERMs were propyl pyrazole triol (PPT), which has more selective effects at ER $\alpha$, than does the other ER $\alpha$ SERM utilized, I 1 - $E_{2}$, which also binds ER $\beta$. ER $\beta$ selective SERMs were diarylpropionitrile (DPN) and 7,I2-dihydrocoumestan (coumestrol). DPN is more selective at ER $\beta$ than coumestrol, which also binds ER $\alpha .17 \beta$ - $E_{2}$ and $E R \beta$-selective SERMs (DPN, coumestrol) produced clear antianxiety behavior in the open field, elevated plus maze, emergence, light-dark transition, defensive freezing, and Vogel punished drinking tasks. Anxiety behavior of rats administered ER $\alpha$-selective SERMs (PPT, I $7 \alpha-E_{2}$ ) was not different from vehicle; however, PPT and I $7 \alpha$ - $E_{2}$ enhanced sexual receptivity in a manner similar to $17 \beta$ - $E_{2}$. Coadministration of tamoxifen $(10 \mathrm{mg} / \mathrm{kg})$ blocked the antianxiety behavior produced by $17 \beta$ - $E_{2}$, DPN, or coumestrol. Together, these data suggest that actions at ER $\beta$ may underlie some of $E_{2}$ 's antianxiety effects.

Neuropsychopharmacology (2005) 30, I598- |609. doi:I0. I038/sj.npp. I3007 I3; published online 30 March 2005
\end{abstract}

Keywords: affect; animal model; estradiol; estrogen receptor; mood; sex differences

\section{INTRODUCTION}

Estradiol $\left(\mathrm{E}_{2}\right)$ may influence the incidence and/or expression of anxiety among women. Generalized anxiety disorder occurs in $\sim 5 \%$ of the general population; however, the incidence increases to $10 \%$ for women aged 40 and older (Wittchen and Hoyer, 2001), a group that has $\mathrm{E}_{2}$ levels that are on the decline. Reports of anxiety are also increased during other periods of relatively low $\mathrm{E}_{2}$ (ie premenstrually, postpartum): whereas, when $\mathrm{E}_{2}$ levels are greater, either naturally or via hormone therapy (HT), women's reports of anxiety decrease (Arpels, 1996; Campbell and Whitehead, 1977; Halbreich, 1997; Torizuka et al, 2000). Some women with premenstrual syndrome treated with transdermal patches of $\mathrm{E}_{2}$ report decreased anxiety (Smith et al, 1995); however, opposite effects are also reported (Schmidt et al, 1998). Together, these findings underscore the importance

\footnotetext{
* Correspondence: Dr CA Frye, Social Science 220, The University at Albany-SUNY, Albany, NY 12222, USA, Tel: + I 518442 4836, Fax: + I 5 I 8442 4247, E-mail: cafrye@albany.edu

Received 8 November 2004; revised 19 January 2005; accepted 2 February 2005

Online publication: 8 February 2005 at http://www.acnp.org/citations/ NPP020805040527/default.pdf
}

of investigating the role, substrates, and mechanisms associated with $\mathrm{E}_{2}$ 's effects on anxiety behavior.

$\mathrm{E}_{2}$ also has antianxiety effects in animal models. On proestrus, when $E_{2}$ levels peak, rats spend more time on the open arms of the elevated plus maze, more time in social interaction with a conspecific, and less time freezing in response to shock than do females in other phases of the estrous cycle or male rats (Fernandez-Guasti et al, 1999; Frye et al, 2000; Mora et al, 1996). Ovariectomy (ovx) typically increases (Diaz-Veliz et al, 1997; Mora et al, 1996; Morgan and Pfaff, 2001; Nomikos and Spyraki, 1988), and $\mathrm{E}_{2}$ replacement decreases (Nomikos and Spyraki, 1988; Frye and Walf, 2004, 2005; Walf and Frye, 2005), anxiety behavior of rodents. For example, ovx rats or mice administered systemic or intrahippocampal $\mathrm{E}_{2}$ spend more time on the open arms of the elevated plus maze than do their vehicle-administered counterparts (Nomikos and Spyraki, 1988; Frye and Walf, 2004, 2005; McCarthy et al, 1996; Walf and Frye, 2005). In the open field task, $E_{2}$ has been reported to produce anxiolytic, anxiogenic, or no effects (Morgan and Pfaff, 2001; Frye and Walf, 2004; Leret et al, 1994; Walf and Frye, 2005). Indeed, the nature of $E_{2}$ 's effects on anxiety behavior seems to depend upon the regimen, and its effects on activity and stress responsiveness (Walf and Frye, 2005). 
There are many possible mechanisms by which $\mathrm{E}_{2}$ can influence anxiety behavior. $\mathrm{E}_{2}$ can act through traditional intracellular $E_{2}$ receptors (ERs), and bind to the $E_{2}$ response element (ERE), or the AP-1 binding site. Although $\mathrm{E}_{2}$ may also have actions independent of ERs, $E_{2}$ 's actions at ERs may influence anxiety behavior. Intact female $\operatorname{ER} \beta$ knockout mice spent less time on the open arms of the elevated plus maze compared to wild type and $\mathrm{ER} \alpha$ knockout mice (Krezel et al, 2001). Similarly, ovx, $\mathrm{E}_{2}$-replaced $\operatorname{ER} \beta$ knockout mice of another strain demonstrated greater anxiety behavior than did their wild-type counterparts in the plus maze (Imwalle et al, 2005). Together, these data support further investigation of $E_{2}$ 's actions via ERs for its effects on anxiety behavior.

Variable effects of $E_{2}$ on anxiety behavior may be related to its actions at the two distinct ERs. Two ER subtypes, ER $\alpha$ and $\operatorname{ER} \beta$, have been discovered and are localized in different areas of the brain. There is $E R \alpha$ mRNA in the ventromedial hypothalamic nucleus and subfornical organ. $\mathrm{ER} \beta$ mRNA seems to be more widely distributed across many regions (olfactory nuclei, zona incerta, ventral tegmental area, cerebellum, laminae III-V, VII, and IX of the spinal cord, pineal gland). Other brain regions containing both $\operatorname{ER} \alpha$ and $\operatorname{ER} \beta$ mRNA include the bed nucleus of the stria terminalis, medial and cortical amygdaloid nuclei, preoptic area, lateral habenula, periaqueductal gray, parabrachial nucleus, locus ceruleus, nucleus of the solitary tract, spinal trigeminal nucleus, and superficial laminae of the spinal cord. As well, both forms of ER mRNA are localized to the cerebral cortex and hippocampus; however, the hybridization signal in these areas is much weaker for $\mathrm{ER} \alpha$ than $\mathrm{ER} \beta$ mRNA (Shughrue et al, 1997). The differential distribution of the two ER subtypes leaves open the possibility that $\operatorname{ER} \alpha$ and $\operatorname{ER} \beta$ may have different behavioral functions.

To begin to dissociate the extent to which actions at $\operatorname{ER} \alpha$ and/or ER $\beta$ mediate estrogens' effects on anxiety behavior, we have begun to examine functional effects of selective ER modulators (SERMs). As there has been very little systematic investigation of behavioral effects of SERMs, we based our hypothesis on evidence that $\mathrm{ER} \alpha$ has an essential role in reproduction (Hewitt and Korach, 2003), the signal for $\operatorname{ER} \beta$ seems to be stronger than the signal for $\mathrm{ER} \alpha$ in the hippocampus, an important brain area for $\mathrm{E}_{2}$ 's modulation of anxiety behavior (Frye et al, 2000; Frye and Walf, 2002, 2005; Shughrue et al, 1997), and recent findings which suggests that $\operatorname{ER} \beta$-selective SERMs are more effective than $\mathrm{ER} \alpha$-selective SERMs or vehicle to modulate affective behavior of ovx female rats (Lund et al, 2005; Walf et al, 2004). Thus, we hypothesized that if actions at $\operatorname{ER} \beta$ mediate antianxiety behavior, then SERMs with more selective activity at $\operatorname{ER} \beta$ would produce greater antianxiety behavior than would SERMs with more selective activity at $\mathrm{ER} \alpha$ or vehicle.

\section{MATERIALS AND METHODS}

These methods were preapproved by the Institutional Animal Care and Use Committee at SUNY Albany.

\section{Animals and Housing}

Female Long-Evans rats $(N=240)$, approximately 55 days old, were obtained from our breeding colony at SUNY-
Albany (original stock from Taconic Farms, Germantown, NY). Rats were group housed (4-5 per cage) in polycarbonate cages $\left(45 \times 24 \times 21 \mathrm{~cm}^{3}\right)$ in a temperature-controlled room $\left(21 \pm 1^{\circ} \mathrm{C}\right)$ in The Laboratory Animal Care Facility. The rats were maintained on a $12 / 12 \mathrm{~h}$ reversed light cycle (lights off 0800 ) with continuous access to Purina Rat Chow and tap water. All rats were ovx under Rompun (12 mg/kg; Bayer Corp., Shawnee Mission, KS) and Ketaset (60 mg/kg; Fort Dodge Animal Health, Fort Dodge, IA) anesthesia 1 week prior to testing.

\section{SERMs}

Rats were administered sesame oil vehicle, $17 \beta-\mathrm{E}_{2}$ (Steraloids, Newport, RI), which has equal affinity for ER $\alpha$ and $\operatorname{ER} \beta$ (Kuiper et al, 1997), or one of the following SERMs, as per our previously published methods (Walf et al, 2004).

ER $\alpha$-specific. SERMs: Propyl pyrazole triol (PPT; Tocris Cookson, Inc., Ellisville, MO) is a potent selective ER agonist that has 410 -fold selectivity for $\operatorname{ER} \alpha$ over $\operatorname{ER} \beta$ (Stauffer et al, 2000). 17 $\alpha-\mathrm{E}_{2}$ (Sigma Chemical Co., St Louis, $\mathrm{MO}$ ) is five times more active at $\operatorname{ER} \alpha$ than $\operatorname{ER} \beta$ (Kupier et al, 1997).

ER $\beta$-specific SERMs: Diarylpropionitrile (DPN; Tocris Cookson, Inc., Ellisville, MO) is a highly selective $\operatorname{ER} \beta$ agonist, with 70 times greater activity at $\operatorname{ER} \beta$ than $\operatorname{ER} \alpha$ (Meyers et al, 2001). 7,12-dihydrocoumestan (coumestrol; Sigma Chemical Co., St Louis, MO) is a less selective $\operatorname{ER} \beta$ agonist, with a sevsen-fold greater affinity for $\operatorname{ER} \beta$ compared to ER $\alpha$ (Kuiper et al, 1997, 1998).

\section{Dosing}

Ovx rats received $10 \mu \mathrm{g}$ SERMs or vehicle s.c. and were tested $48 \mathrm{~h}$ later. This regimen was based upon our previous investigation of dose-dependent effects of $\mathrm{E}_{2}$ on anxiety behavior. Compared to lower or higher dosages, $5-10 \mu \mathrm{g}$ $17 \beta-\mathrm{E}_{2}$ s.c. to young, ovx rats is most effective at producing physiological plasma levels of $\mathrm{E}_{2}$ and antianxiety behavior, $48 \mathrm{~h}$ later (Walf and Frye, 2005). As well, this $\mathrm{E}_{2}$ regimen is commonly employed to induce sexual receptivity in rats (Frye et al, 1998). Although in some cases, higher concentrations of DPN and/or PPT are necessary to induce the same biological activity as $\mathrm{E}_{2}$ (Handa et al, 1986, 1987), $10 \mu \mathrm{g}$ concentrations were utilized for all SERMs, to minimize loss of selective actions at ERs, and/or specific behavioral effects, that might be produced by supraphysiological and/or chronic SERM regimen. We have also used this regimen of SERM-administration successfully to examine $\mathrm{E}_{2}$ 's modulation of depressive behavior of ovx rats in the forced swim test (Walf et al, 2004).

\section{ER Blockade}

Some rats were coadministered tamoxifen $(10 \mathrm{mg} / \mathrm{kg}$ s.c.), or vehicle, in conjunction with behaviorally effective SERMs and were tested, $48 \mathrm{~h}$ later. Tamoxifen was utilized because it is a nonselective, but effective, ER antagonist that readily penetrates the blood-brain barrier. This tamoxifen regimen blocks lordosis facilitated by s.c. $\mathrm{E}_{2}$ (Etgen and Shamamian, 1986). 


\section{Procedure}

Experiment 1. To determine effects of ER $\alpha$ - and ER $\beta$ selective SERMs for sexual receptivity, ovx rats ( $n=10$ /grp) were randomly assigned to receive oil vehicle or $10 \mu \mathrm{g} 17 \beta$ $\mathrm{E}_{2}$, PPT, $17 \alpha-\mathrm{E}_{2}$, DPN, or coumestrol $48 \mathrm{~h}$ before testing for sexual receptivity with a stimulus male and motor behavior in the horizontal crossing task.

Experiment 2. To determine effects of $\mathrm{ER} \alpha$ - and $\mathrm{ER} \beta$ selective SERMs for anxiety behavior, ovx rats $(n=10$ /grp) were randomly assigned to receive oil vehicle or $10 \mu \mathrm{g} 17 \beta$ $\mathrm{E}_{2}$, PPT, $17 \alpha-\mathrm{E}_{2}, \mathrm{DPN}$, or coumestrol $48 \mathrm{~h}$ before anxiety testing.

Experiment 3. To determine whether effects of $\mathrm{ER} \beta$ selective SERMs for anxiety behavior can be attenuated with coadministration of an ER antagonist, ovx rats $(n=10 /$ grp) were randomly assigned to receive vehicle or tamoxifen $\left(10 \mathrm{mg} / \mathrm{kg}\right.$ s.c.), followed by $10 \mu \mathrm{g}$ of $17 \beta-\mathrm{E}_{2}, \mathrm{DPN}$, or coumestrol. Rats were then tested $48 \mathrm{~h}$ later for anxiety behavior.

\section{Behavioral Testing}

Rats in Experiment 1 were tested for sexual receptivity, whereas rats in Experiments 2 and 3 were tested for anxiety behavior in the following tasks. In Experiments 2 and 3, some rats were sequentially tested once a week, for up to 4 weeks, until performance in each task was examined. Other rats were only tested in a single task. No rats were ever tested more than once in any given task because of known test-decay effects in most measures of anxiety behavior.

Sexual receptivity. Rats were tested for sexual behavior in a Plexiglas chamber $\left(50 \times 25 \times 30 \mathrm{~cm}^{3}\right)$ with an intact male for 10 mounts or $10 \mathrm{~min}$, whichever occurred first, by an observer who was blind to rats' experimental conditions. The frequency of lordosis (lordosis quotient) and the intensity of lordosis (lordosis ratings; LR), quantified by rating dorsiflexion during lordosis on a scale of $0-3$, exhibited by experimental female rats were recorded (Frye et al, 1998; Hardy and DeBold, 1971).

Horizontal crossing task. Immediately after testing for sexual receptivity, rats were tested in the horizontal crossing task as per Frye et al (2000). Rats were placed in a $39 \times 39 \times 30 \mathrm{~cm}^{3}$ Digiscan Optical Animal Activity Monitor (Accuscan Instruments Inc., Columbus, $\mathrm{OH}$ ) that mechanically recorded the number of beam breaks that occurred during a 5-min period.

Open field. The open field task was used in accordance with previously published methods (Frye et al, 2000; McCarthy et al, 1995). The open field $\left(76 \times 57 \times 35 \mathrm{~cm}^{3}\right)$ has a 48 square grid floor $(6 \times 8$ squares, $9.5 \mathrm{~cm} / \mathrm{side})$, and an overhead light illuminating the central squares (all but the 24 perimeter squares are considered central). The number of central and peripheral squares (summed for total) entered during a 5-min period were recorded.
Elevated plus-maze. The methods previously described by Frye et al (2000) were utilized. The elevated plus-maze consisted of four arms, $49 \mathrm{~cm}$ long and $10 \mathrm{~cm}$ wide, elevated $50 \mathrm{~cm}$ off the ground. Two arms are enclosed by walls $30 \mathrm{~cm}$ high and the other two arms are exposed. Rats are placed at the junction of the open and closed arms. The number of entries, and the amount of time spent, on the open and closed arms during a 5-min period were recorded.

Emergence test. As previously described (Frye et al, 2000), rats were placed in a closed opaque cylinder $\left(21 \times 7 \times 7 \mathrm{~cm}^{3}\right)$ that was set in an open field and secured to prevent rolling. The lid of the cylinder was removed and the latency for the rat to emerge completely from the cylinder was recorded (maximum latency $5 \mathrm{~min}$ ).

Light-dark transition task. Rats were placed on the side of a two-chambered box $\left(30 \times 40 \times 40 \mathrm{~cm}^{3}\right)$ with white walls and floor and illuminated by a $40-\mathrm{W}$ light from above; the other side of the box was painted black and had a lid so it was not illuminated. For 5-min, the time spent on the light side of this chamber compared to the dark side was recorded (Chaouloff et al, 1997).

Defensive freezing. The defensive freezing procedure utilized was according to methods previously reported (Frye et al, 2000). Briefly, rats were placed in a clear Plexiglas chamber $\left(26.0 \times 21.2 \times 24.7 \mathrm{~cm}^{3}\right)$. In the right rear corner was a pedestal $(2.5 \mathrm{~cm}$ diameter, $10.0 \mathrm{~cm}$ height $)$, which was wrapped by wires connected to a shock source (Lafayette Model A615B, Lafayette, IN) set to deliver $6.66 \mathrm{~mA}$ of unscrambled shock, initiated by the experimenter and terminated by the rats' withdrawal of its paws. The response to footshock was recorded by the experimenter as a flinch-jump rating $(1=$ flinch, $2=$ jump, $3=$ jump and squeak). The latency to touch the shock prod, and the time spent freezing in response to shock, was recorded for $15 \mathrm{~min}$.

Vogel punished drinking task. After $24 \mathrm{~h}$ of water deprivation, rats were placed in a clear plexiglas chamber with a metal grid floor $\left(44 \times 22 \times 20 \mathrm{~cm}^{3}\right.$; Brocco et al, 1990). An electrified water bottle was suspended from the ceiling of the chamber and connected to a computer interface (Anxio-meter, Columbus Instruments, Colombus, $\mathrm{OH})$ that automatically recorded the number of licks and shocks (one shock for every 20 licks) that the rat received during the 3-min test. The test began after the rat made an initial 20 licks and received its first shock $(0.3 \mathrm{~mA}$ for $2 \mathrm{~s})$. Rats had a maximum latency of $15 \mathrm{~min}$ to begin the test. Data were excluded from rats that did not fulfill this criteria $(n=4)$.

\section{Statistical Analyses}

In Experiments 1 and 2, one-way analyses of variance (ANOVAs) were utilized to determine if there were differences among SERMs' effects on behavior. In Experiment 3, two-way ANOVAs were utilized to determine if there were differences among SERMs' and tamoxifen's effects on behavior. The $\alpha$ level for statistical significance 
was $p \leqslant 0.05$ and a trend was considered $p \leqslant 0.10$. Where appropriate, post hoc tests used to determine group differences were Fisher's tests with Boneferroni corrections.

\section{RESULTS}

\section{Experiment 1: Effects of SERMs for Sexual Receptivity and Horizontal Crossing}

There were effects of $17 \beta$ - $E_{2}$ and ER $\alpha$-selective SERMs to enhance sexual receptivity compared to vehicle or ER $\beta$ selective SERMs. There were differences among groups in the lordosis quotients of rats in response to mounting by a stimulus male $\left(\mathrm{F}_{5,54}=4.86 ; p<0.01\right)$. Post hoc tests revealed that administration of $17 \beta-\mathrm{E}_{2}$, PPT, or $17 \alpha-\mathrm{E}_{2}$ significantly increased lordosis quotients compared to vehicle, DPN, or coumestrol (see Figure 1).

There were no significant differences among groups of rats administered vehicle $(704 \pm 66), 17 \beta-\mathrm{E}_{2}(720 \pm 128)$, PPT $(788 \pm 97), 17 \alpha-\mathrm{E}_{2}(943 \pm 80), \quad \mathrm{DPN}(867 \pm 111)$, or coumestrol $(826 \pm 77)$ in the number of beam breaks made in the horizontal crossing task $(p=0.49)$.

\section{Experiments 2 and 3: Effects of SERMS and/or Tamoxifen on Anxiety Behavior}

Open field. $17 \beta$ - $\mathrm{E}_{2}$ and $\mathrm{ER} \beta$-selective SERMs produced antianxiety effects in the open field task compared to vehicle or ER $\alpha$-selective SERMs. There were differences among groups in the number of central $\left(\mathrm{F}_{5,54}=3.19\right.$; $p<0.01$; see Figure $2 \mathrm{a})$ and total entries $\left(\mathrm{F}_{5,54}=2.69\right.$; $p<0.03$; see Table 1) made in the brightly-lit open field. Post hoc tests revealed that $17 \beta-\mathrm{E}_{2}, \mathrm{DPN}$, or coumestrol (which all bind $\operatorname{ER} \beta$ ), significantly increased the number of central entries made compared to rats administered vehicle. $17 \beta-\mathrm{E}_{2}$ significantly increased the number of central entries compared to PPT or $17 \alpha-\mathrm{E}_{2}$.

As was observed for the first group of rats tested in Experiment 2, $17 \beta-\mathrm{E}_{2}$ and $\mathrm{ER} \beta$-selective SERMs had antianxiety effects in the open field task in Experiment 3. Significant differences among groups in the number of central entries $\left(\mathrm{F}_{3,72}=4.67 ; p<0.01\right.$; Figure $\left.2 \mathrm{~b}\right)$ were due to $17 \beta-\mathrm{E}_{2}$, DPN or coumestrol having more central entries compared to vehicle-administered rats. There was a tendency for differences among groups for peripheral entries $\left(\mathrm{F}_{3,72}=2.12 ; p<0.10\right.$; Table 1$)$, such that rats administered $17 \beta-\mathrm{E}_{2}$ entered more peripheral squares than did rats administered vehicle or DPN.

Tamoxifen, compared to vehicle administration, attenuated antianxiety effects in the open field task. Tamoxifen significantly decreased the number of central $\left(\mathrm{F}_{1,72}=20.95\right.$; $p<0.01)$, but not peripheral $(p=0.12)$, entries compared to vehicle administration.

There was a significant interaction between SERM administration and tamoxifen administration on behavior in the open field task. Rats that were coadministered $17 \beta$ - $E_{2}$, DPN, or coumestrol, but not vehicle, and tamoxifen, had significantly fewer central entries $\left(\mathrm{F}_{3,72}=2.67 ; p<0.05\right)$, but no differences in peripheral entries $(p=0.27)$, in the open field compared to rats that were coadministered SERMs and vehicle.

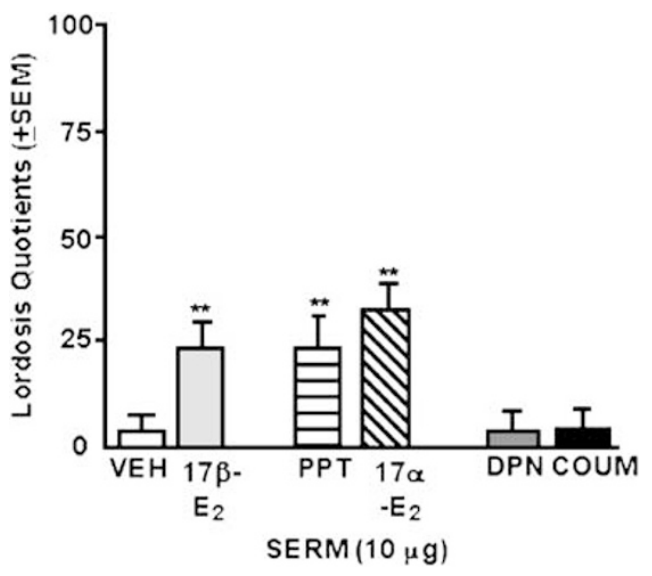

Figure I The mean $( \pm$ SEM) lordosis quotients of ov $x$ rats administered vehicle, 17 $\beta-\mathrm{E}_{2}$, PPT, 17 $\alpha-\mathrm{E}_{2}$, DPN, coumestrol (COUM) $48 \mathrm{~h}$ before testing ( $n=10 /$ condition). $* *$ above bar indicates a significant difference from vehicle, DPN, and coumestrol $(p<0.05)$.
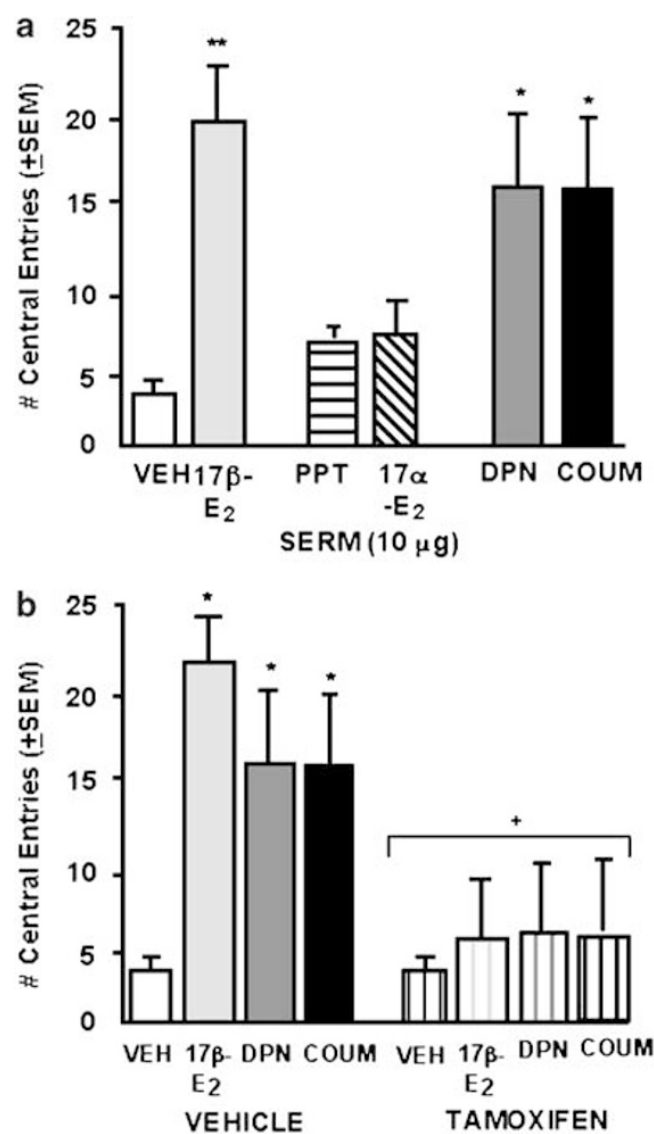

Figure 2 (a) The mean ( \pm SEM) central entries in the open field of ovx rats administered vehicle, 17 $1-E_{2}, \quad P P T, 17 \alpha-E_{2}, \quad D P N$, coumestrol (COUM) $48 \mathrm{~h}$ before testing ( $n=10 /$ condition). (b) The mean ( \pm SEM) central entries in the open field of ovx rats coadministered vehicle (solid bars) or tamoxifen (striped bars) and vehicle, $17 \beta-E_{2}$, COUM, or DPN $48 \mathrm{~h}$ before testing $(n=10 /$ condition). * above bar indicates a significant difference from vehicle. *** above bar indicates a significant difference from vehicle, PPT, and $17 \alpha-E_{2}$. + above grouped bars indicates a significant effect of coadministration of tamoxifen compared to vehicle $(p<0.05)$. 
Table I Open Field Peripheral Entries, Elevated Plus Maze Open and Closed Arm Entries and Closed Arm Time and Defensive Freezing Task Latencies to Touch Shock Prod and Flinch-Jump Ratings

\begin{tabular}{|c|c|c|c|c|c|c|}
\hline & $\begin{array}{l}\text { Peripheral } \\
\text { entries }\end{array}$ & $\begin{array}{l}\text { Open arm } \\
\text { entries }\end{array}$ & $\begin{array}{c}\text { Closed arm } \\
\text { entries }\end{array}$ & $\begin{array}{l}\text { Closed arm } \\
\text { time }\end{array}$ & $\begin{array}{l}\text { Latency to touch } \\
\text { shock prod }\end{array}$ & $\begin{array}{c}\text { Flinch-jump } \\
\text { ratings }\end{array}$ \\
\hline \multicolumn{7}{|l|}{$\operatorname{SERM}(10 \mu \mathrm{g})$} \\
\hline $17 \beta-\mathrm{E}_{2}$ & $86.8 \pm 11.5$ & $2.0 \pm 0.4 * * *$ & $5.6 \pm 0.8$ & $272.5 \pm 3.9 * *$ & $|54| \pm 50.3$. & $1.6 \pm 0.2$ \\
\hline PPT & $74.8 \pm 7.4$ & $0.6 \pm 0.2$ & $3.3 \pm 0.5$ & $294.4 \pm 2.9$ & $115.9 \pm 21.9$ & $1.9 \pm 0.2$ \\
\hline Coumestrol & $112.9 \pm 16.7$ **** & $2.3 \pm 0.9 * *$ & $6.2 \pm 1.1$ & $274.5 \pm 10.8^{* * *}$ & $61.8 \pm 20.2$ & $1.5 \pm 0.2$ \\
\hline \multicolumn{7}{|c|}{ SERM $(10 \mu \mathrm{g})$ and tamoxifen $(10 \mathrm{mg} / \mathrm{kg})$ treatment } \\
\hline Vehicle+vehicle & $65.8 \pm \mid 5.1$ & $0.3 \pm 0.2$ & $3.1 \pm 0.4$ & $297.5 \pm 1.7$ & $151.3 \pm 42.9$ & $1.6 \pm 0.2$ \\
\hline Vehicle $+17 \beta-E_{2}$ & $89.9 \pm 11.6 *$ & $1.8 \pm 0.4$ & $5.7 \pm 1.1$ & $281.2 \pm 3.7 *$ & $71.8 \pm 24.0$ & $1.9 \pm 0.2$ \\
\hline Tamoxifen $+17 \beta-E_{2}$ & $92.6 \pm 13.4 *$ & $0.4 \pm 0.2^{\dagger}$ & $4.5 \pm 1.1$ & $298.4 \pm 0.7^{\dagger}$ & $38.2 \pm 12.1$ & $1.5 \pm 0.2$ \\
\hline Tamoxifen+coumestrol & $76.2 \pm 12.0$ & $0.5 \pm 0.2^{\dagger}$ & $5.7 \pm 1.1$ & $297.4 \pm 1.3^{\dagger}$ & $125.9 \pm 39.8$ & $1.5 \pm 0.2$ \\
\hline Tamoxifen+DPN & $49.9 \pm 11.3$ & $0.4 \pm 0.2^{\dagger}$ & $6.7 \pm 1.1$ & $298.0 \pm 1.1^{\dagger}$ & $68.0 \pm 14.2$ & $2.1 \pm 0.2$ \\
\hline
\end{tabular}

*Significant difference from vehicle $(p<0.05)$; ** Significant difference from vehicle, PPT, and I $7 \alpha-E_{2}(p<0.05)$; ${ }^{\dagger}$ Significant effect of tamoxifen compared to vehicle $(p<0.05)$.

Elevated plus maze. There were antianxiety effects of $17 \beta$ $\mathrm{E}_{2}$ and $\mathrm{ER} \beta$-selective SERMs administration in the elevated plus maze. There were differences among groups in the number of entries $\left(\mathrm{F}_{5,54}=4.21 ; p<0.01\right.$; see Table 1$)$ and duration of time spent on the open arms of the maze $\left(\mathrm{F}_{5,54}=5.00 ; p<0.01\right.$; see Figure $\left.3 \mathrm{a}\right)$. Similarly, there was a trend for groups to be different in the number of closed arm entries $\left(\mathrm{F}_{5,54}=2.22 ; p<0.06\right)$ and significant differences among groups for duration spent on the closed arms of the plus maze $\left(\mathrm{F}_{5,54}=5.06 ; p<0.01\right.$; see Table 1$)$. Post hoc tests revealed that rats administered $17 \beta-\mathrm{E}_{2}, \mathrm{DPN}$, or coumestrol made more open arm entries, spent more time on the open arms, and less time on the closed arms of the maze than did rats administered vehicle, PPT, or $17 \alpha-E_{2}$. DPN or coumestrol-administered rats also made more entries on the closed arms of the plus maze compared to rats administered PPT or $17 \alpha-\mathrm{E}_{2}$.

As in Experiment 2, there was a main effect of SERM administration on behavior in the elevated plus maze in Experiment 3. Rats administered $17 \beta-\mathrm{E}_{2}$, DPN, or coumestrol spent more time on the open arms $\left(\mathrm{F}_{3,72}=5.21\right.$; $p<0.01$; see Figure $3 b$ ), less time on the closed arms $\left(\mathrm{F}_{3,72}=5.28 ; p<0.01\right.$; see Table 1$)$, and tended to make more open arm entries $\left(\mathrm{F}_{3,72}=2.48 ; p<0.06\right.$; Table 1$)$ than did rats administered vehicle. There was no main effect of SERM administration on the number of closed arm entries made $(p=0.11)$.

There was a main effect of tamoxifen administration on behavior in the elevated plus maze. Tamoxifen administration significantly decreased the duration spent $\left(\mathrm{F}_{1,72}=54.42 ; p<0.01\right)$, and entries made $\left(\mathrm{F}_{1,72}=21.43\right.$; $p<0.01$ ), on the open arms and increased the duration spent on the closed arms $\left(\mathrm{F}_{1,72}=50.12 ; p<0.01\right)$ of the maze compared to vehicle. There was no main effect of tamoxifen administration on the number of closed arm entries made $(p=0.27)$.

There was a significant interaction between SERM and tamoxifen administration on behavior in the elevated plus maze. $17 \beta-E_{2}$, DPN, or coumestrol, but not vehicle, coadministered with tamoxifen significantly decreased the time spent $\left(\mathrm{F}_{3,72}=7.16 ; p<0.01\right)$ and entries $\left(\mathrm{F}_{3,72}=5.15\right.$; $p<0.01)$ on the open arms, and increased the duration spent on the closed arms of the plus maze $\left(\mathrm{F}_{3,72}=7.13\right.$; $p<0.01)$. There was no interaction for the number of closed arm entries made $(p=0.30)$.

Emergence task. In the emergence task, there were antianxiety effects of $17 \beta-\mathrm{E}_{2}$ and $\mathrm{ER} \beta$-selective SERMs compared to vehicle or ER $\alpha$-selective SERMs. There were differences among groups in the latency to emerge from a cylinder $\left(\mathrm{F}_{5,54}=3.28 ; p<0.01\right.$; see Figure $\left.4 \mathrm{a}\right)$. Post hoc tests revealed that administration of $17 \beta-\mathrm{E}_{2}, \mathrm{DPN}$, or coumestrol significantly reduced the latency to emerge from a cylinder compared to vehicle, PPT, or $17 \alpha-\mathrm{E}_{2}$.

Consistent with results from Experiment 2, there was evidence for antianxiety effects of $17 \beta-\mathrm{E}_{2}, \quad \mathrm{DPN}$, and coumestrol, compared to vehicle in Experiment 3. There was a tendency for groups to be different for the latency to emerge from a cylinder $\left(\mathrm{F}_{3,72}=2.13 ; p<0.10\right.$; see Figure $\left.4 \mathrm{~b}\right)$.

There was a significant main effect of tamoxifen administration on emergence latencies $\left(\mathrm{F}_{1,72}=23.45\right.$; $p<0.01)$. Rats administered tamoxifen had significantly longer latencies to emerge from a cylinder than did rats administered vehicle. 

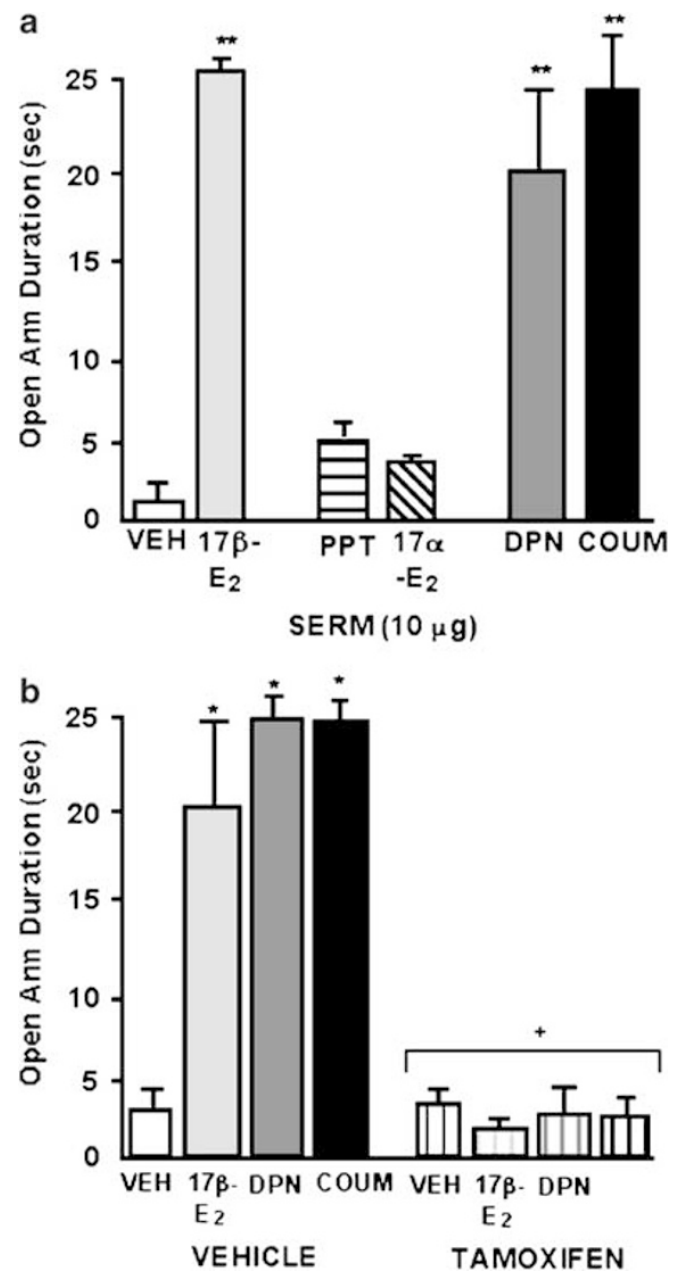

Figure 3 (a) The mean ( \pm SEM) duration spent on the open arms of the plus maze of ovx rats administered vehicle, $17 \beta-E_{2}, P P T, 17 \alpha-E_{2}$, DPN, coumestrol (COUM) $48 \mathrm{~h}$ before testing ( $n=10 /$ condition). (b) The mean $( \pm$ SEM) duration spent on the open arms of the plus maze of ovx rats coadministered vehicle (solid bars) or tamoxifen (striped bars) and vehicle, $17 \beta-E_{2}$, COUM, or DPN $48 \mathrm{~h}$ before testing ( $n=10 /$ condition). * above bar indicates a significant difference from vehicle. ** above bar indicates a significant difference from vehicle, PPT, and $17 \alpha-E_{2} .+$ above grouped bars indicates a significant effect of coadministration of tamoxifen compared to vehicle $(p<0.05)$.

There was a significant interaction between SERM and tamoxifen administration on emergence latencies. Coadministration of tamoxifen with $17 \beta-\mathrm{E}_{2}$, DPN, or coumestrol, but not vehicle, significantly increased the latency to emerge $\left(\mathrm{F}_{3,72}=2.92 ; p<0.04\right)$ compared to coadministration of SERMs and vehicle.

Light-dark transition. There were antianxiety effects of $17 \beta-\mathrm{E}_{2}$ and $\mathrm{ER} \beta$-selective SERMs compared to vehicle or ER $\alpha$-selective SERMs in the light-dark transition task. There was a tendency for groups to differ in the duration of time spent on the light side of the chamber $\left(\mathrm{F}_{5,54}=2.02\right.$; $p<0.01$; see Figure 5a). Post hoc tests revealed that administration of $17 \beta-E_{2}$, DPN, or coumestrol increased the time spent on the light side of the chamber compared to vehicle, PPT, or $17 \alpha-\mathrm{E}_{2}$.
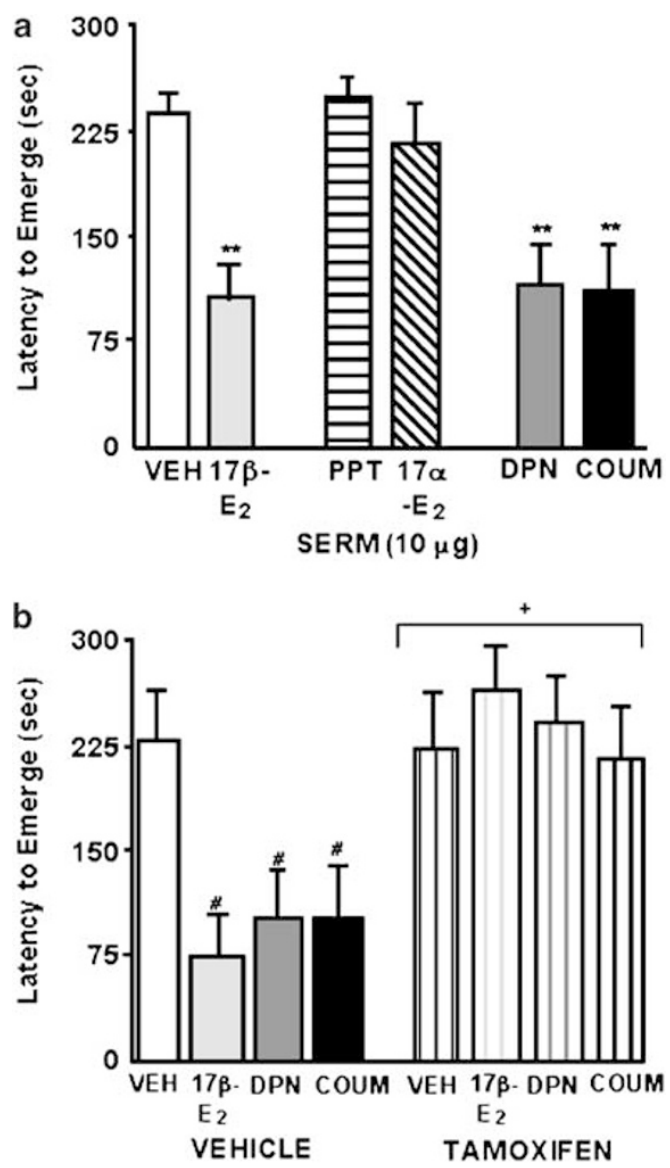

Figure 4 (a) The mean ( \pm SEM) latency to emerge from a dark chamber of ovx rats administered vehicle, 17 $\beta-E_{2}$, PPT, I7 $\alpha-E_{2}$, DPN, coumestrol (COUM) $48 \mathrm{~h}$ before testing ( $n=10 /$ condition). (b) The mean ( \pm SEM) latency to emerge from a dark chamber of ovx rats coadministered vehicle (solid bars) or tamoxifen (striped bars) and vehicle, $17 \beta-E_{2}, C O U M$, or DPN $48 \mathrm{~h}$ before testing ( $n=10 /$ condition). * above bar indicates a significant difference from vehicle. ** above bar indicates a significant difference from vehicle, PPT, and $17 \alpha-E_{2}$. + above grouped bars indicates a significant effect of coadministration of tamoxifen compared to vehicle $(p<0.05)$. \# indicates a tendency to be different compared to vehicle, PPT, and $17 \alpha-E_{2}(p<0.10)$.

Similar to effects observed in Experiment 2, there was a main effect of SERM administration on behavior in the light-dark transition task in Experiment 3. Rats administered $17 \beta-\mathrm{E}_{2}$, DPN, or coumestrol spent more time in the light side of chamber $\left(\mathrm{F}_{3,72}=5.27 ; p<0.02\right.$; see Figure $\left.5 \mathrm{~b}\right)$ than did rats administered vehicle.

There was a main effect of tamoxifen administration on behavior in the light-dark transition task. Tamoxifen administration significantly decreased the duration spent on the light side of the chamber $\left(\mathrm{F}_{1,72}=3.97 ; p<0.05\right)$ compared to vehicle.

Defensive freezing task. In the defensive freezing task, there were antianxiety effects of $17 \beta-\mathrm{E}_{2}$ and $\mathrm{ER} \beta$-selective SERMs compared to vehicle or ER $\alpha$-selective SERMs. There were differences among groups in the time spent freezing after a footshock in this task $\left(\mathrm{F}_{5,54}=17.74 ; p<0.01\right.$; see Figure $\left.6 \mathrm{a}\right)$. 

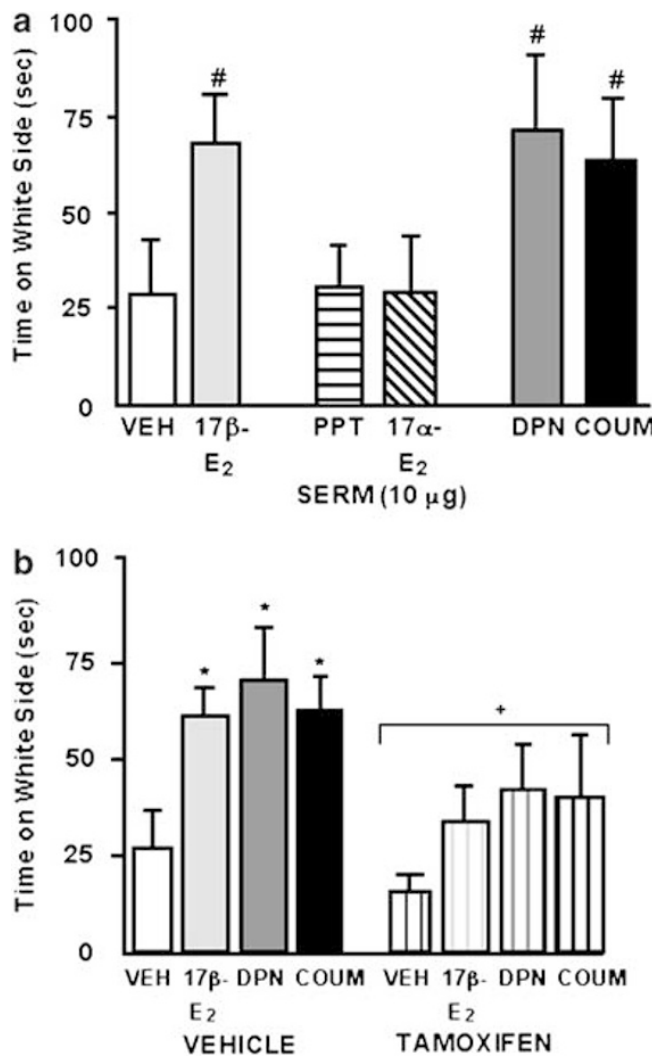

Figure 5 (a) The mean $( \pm$ SEM) duration spent on the white side of the chamber in the light-dark transition task of ovx rats administered vehicle, 17 $\beta$ - $\mathrm{E}_{2}$, PPT, 17 $\alpha-\mathrm{E}_{2}$, DPN, coumestrol (COUM) $48 \mathrm{~h}$ before testing ( $n=10 /$ condition). (b) The mean ( \pm SEM) duration spent on the white side of the chamber in the light-dark transition task of ovx rats coadministered vehicle (solid bars) or tamoxifen (striped bars) and vehicle, $17 \beta$ - $E_{2}$, COUM, or DPN $48 \mathrm{~h}$ before testing ( $n=10 /$ condition). * above bar indicates a significant difference from vehicle. *** above bar indicates a significant difference from vehicle, PPT, and $17 \alpha-E_{2} .+$ above grouped bars indicates a significant effect of coadministration of tamoxifen compared to vehicle $(p<0.05)$. \# indicates a tendency to be different compared to vehicle, PPT, and $17 \alpha-E_{2}(p<0.10)$.

Post hoc tests revealed that administration of $17 \beta-\mathrm{E}_{2}$, DPN, or coumestrol significantly reduced the time spent freezing compared to vehicle, PPT, or $17 \alpha-\mathrm{E}_{2}$. Administration of SERMs, except for coumestrol, increased latencies of rats to touch the shock prod compared to vehicle-administration, but significant differences were not observed $(p=0.40$; see Table 1). Similarly, there were no differences among groups on their flinch-jump reaction to footshock $(p=0.73$; see Table 1).

As in Experiment 2, there was a main effect of SERMadministration for behavior in the defensive freezing task in Experiment $3 \quad\left(\mathrm{~F}_{3,72}=18.18 ; p<0.01 ;\right.$ Figure $\left.6 \mathrm{~b}\right)$. Rats administered $17 \beta-\mathrm{E}_{2}, \mathrm{DPN}$, or coumestrol spent significantly less time freezing after footshock than did vehicleadministered rats.

There was a significant main effect of tamoxifen on freezing behavior in the defensive freezing task. Tamoxifen significantly increased freezing behavior following footshock than did vehicle-administration $\left(F_{1,72}=37.21\right.$; $p<0.01$ ).

There was a significant interaction between SERM and tamoxifen administration. Coadministration of tamoxifen
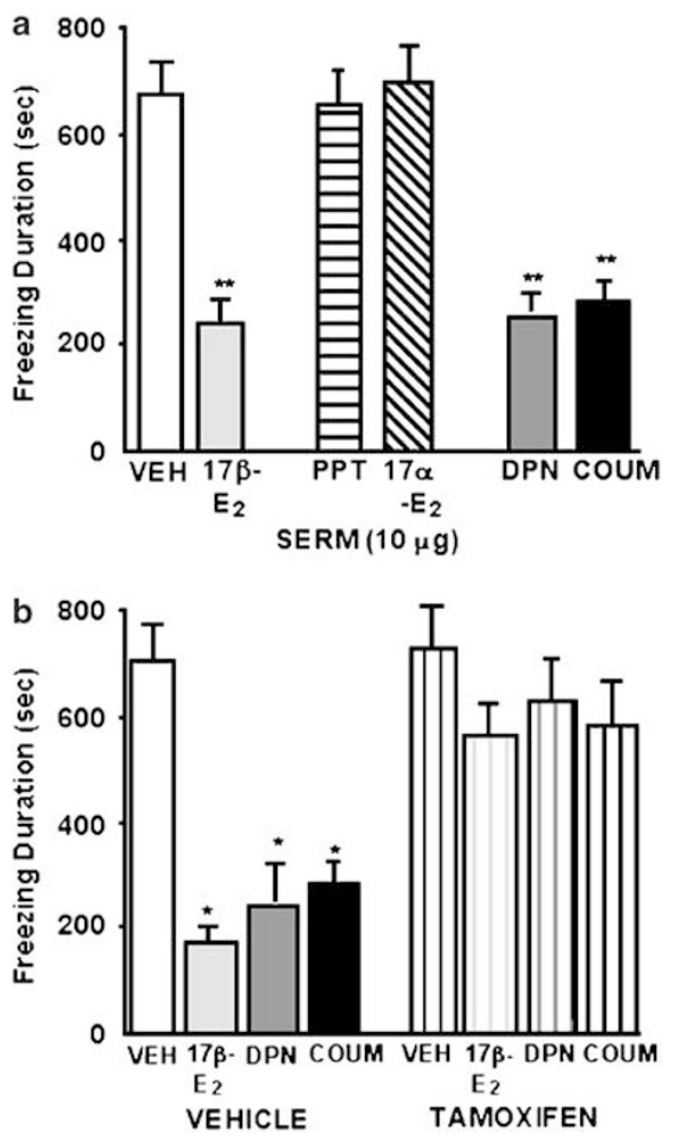

Figure 6 (a) The mean $( \pm$ SEM) duration spent freezing post-footshock in the defensive freezing task of ov $x$ rats administered vehicle, 17 $\beta$ - $E_{2}$, PPT, $17 \alpha-E_{2}$, DPN, coumestrol (COUM) $48 \mathrm{~h}$ before testing ( $n=10 /$ condition). (b) The mean $( \pm S E M)$ duration spent freezing post-footshock in the defensive freezing task of ovx rats coadministered vehicle (solid bars) or tamoxifen (striped bars) and vehicle, $17 \beta$ - $\mathrm{E}_{2}$, COUM, or DPN $48 \mathrm{~h}$ before testing ( $n=10 /$ condition). * above bar indicates a significant difference from vehicle. ** above bar indicates a significant difference from vehicle, PPT, and $17 \alpha-E_{2}$. + above grouped bars indicates a significant effect of coadministration of tamoxifen compared to vehicle $(p<0.05)$.

and $17 \beta-\mathrm{E}_{2}$, DPN, or coumestrol, but not vehicle, significantly increased time spent freezing by rats $\left(\mathrm{F}_{3,72}=4.54\right.$; $p<0.01)$.

In Experiment 3, there was a tendency for SERM treatment to alter touch latencies in the defensive freezing task $\left(\mathrm{F}_{3,72}=2.42 ; p<0.07\right)$, such that rats administered vehicle or coumestrol had longer latencies than rats administered $17 \beta-\mathrm{E}_{2}$ (see Table 1 ). There was no significant main effect of tamoxifen treatment $(p=0.36)$, nor an interaction between SERM and tamoxifen treatment $(p=0.46)$, on this measure.

There were no significant main effects of SERM $(p=0.23)$ or tamoxifen administration $(p=0.52)$ or interactions of both treatments $(p=0.28)$ on flinch-jump ratings to footshock in this task.

Vogel punished drinking task. There were antianxiety effects of $17 \beta$-E $E_{2}$ and ER $\beta$-selective SERMs compared to vehicle or ER $\alpha$-selective SERMs in the Vogel punished drinking task. There were differences among groups in the number of punished (shock-associated) licks made $\left(\mathrm{F}_{5,54}=6.03 ; p<0.01\right.$; see Figure $\left.7 \mathrm{a}\right)$. Post hoc tests revealed 

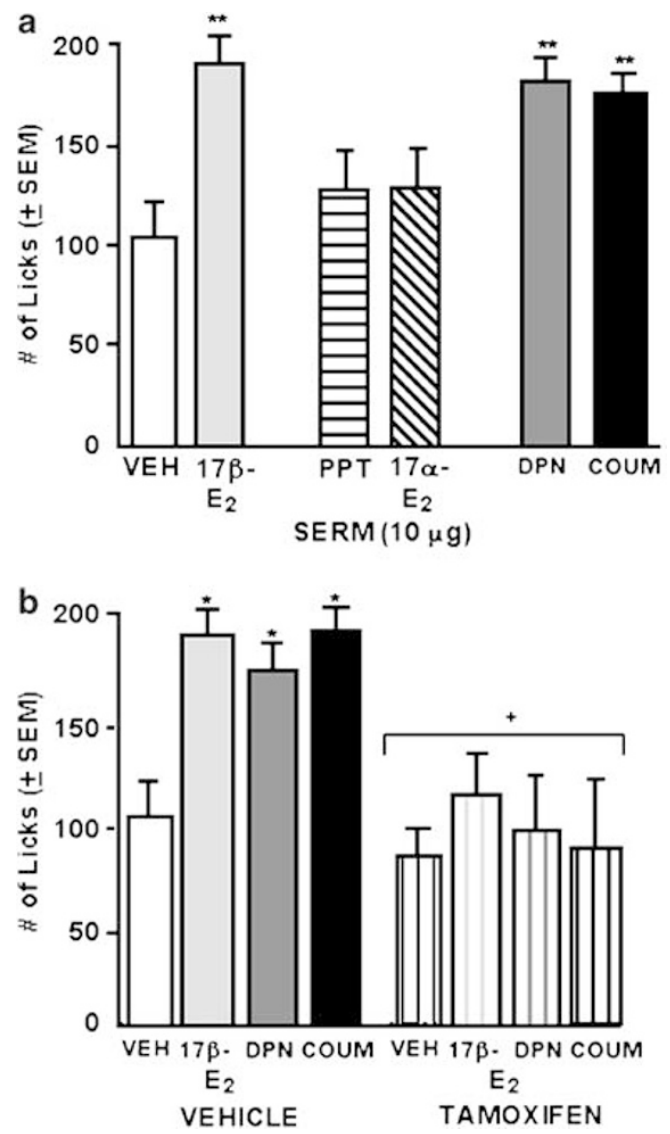

Figure 7 (a) The mean $( \pm$ SEM) number of punished licks made in the Vogel task of ovx rats administered vehicle, $17 \beta-E_{2}, \mathrm{PPT}, 17 \alpha-\mathrm{E}_{2}$, DPN, coumestrol (COUM) $48 \mathrm{~h}$ before testing ( $n=10 /$ condition). (b) The mean $( \pm$ SEM) number of punished licks made in the Vogel task of ovx rats coadministered vehicle (solid bars) or tamoxifen (striped bars) and vehicle, $17 \beta$ - $E_{2}$, COUM, or DPN $48 \mathrm{~h}$ before testing ( $n=7-10 /$ condition). * above bar indicates a significant difference from vehicle. ** above bar indicates a significant difference from vehicle, PPT, and $17 \alpha-E_{2}$. + above grouped bars indicates a significant effect of coadministration of tamoxifen compared to vehicle $(p<0.05)$

that administration of $17 \beta-\mathrm{E}_{2}$, DPN, or coumestrol significantly increased the number of punished licks made compared to vehicle, PPT, or $17 \alpha-\mathrm{E}_{2}$.

Consistent with results from Experiment 2, there was evidence for antianxiety effects of $17 \beta-\mathrm{E}_{2}$, DPN, and coumestrol, compared to vehicle in the Vogel punished drinking task $\left(\mathrm{F}_{3,72}=2.96 ; \quad p<0.04\right.$; see Figure $7 \mathrm{~b})$. Post hoc tests revealed that administration of $17 \beta-\mathrm{E}_{2}, \mathrm{DPN}$, or coumestrol increased punished licks compared to vehicle.

There was a significant main effect of tamoxifen administration on number of punished licks made. Rats administered tamoxifen made significantly less punished licks than did rats administered vehicle $\left(\mathrm{F}_{1,72}=10.74\right.$; $p<0.01)$.

\section{DISCUSSION}

The hypothesis that SERMs with actions at ER $\beta$ produce specific antianxiety behavioral effects was supported. $17 \beta$ -
$\mathrm{E}_{2}$, which binds to both $\mathrm{ER} \alpha$ and $\mathrm{ER} \beta$, DPN (a highly specific ER $\beta$-selective SERM) and coumestrol (an SERM with greater activity at $\operatorname{ER} \beta$ than $\operatorname{ER} \alpha$ ), increased the time spent in the center of the brightly-lit open field and time spent on the open arms of the elevated plus maze compared to vehicle; whereas ER $\alpha$-selective SERMs, PPT, and $17 \alpha-E_{2}$, did not. Similarly, $17 \beta-E_{2}, D P N$, and coumestrol also produced significantly shorter emergence latencies, longer durations spent on the light side in the light-dark transition task, less time freezing in response to shock, and more punished licks than did vehicle, PPT, or $17 \alpha-\mathrm{E}_{2}$. Additionally, the antianxiety effects of $17 \beta-\mathrm{E}_{2}$, DPN, and coumestrol were abrogated by coadministration of the nonselective ER antagonist tamoxifen, but not vehicle. These data suggest that activity at $\operatorname{ER} \beta$ may be sufficient to produce antianxiety behavior.

The present results support previous findings that suggest that actions at $\operatorname{ER} \beta$ may have a role in mediating affective behaviors. Studies have shown effects of dietary phytoestrogens, with a greater affinity for $\operatorname{ER} \beta$, influence anxiety behavior. Exposure to dietary genistein, an SERM with activity at $\operatorname{ER} \beta$, throughout gestation and until postnatal day 75 , reduced anxiety behavior of male and female LongEvans rats in the elevated plus maze (Lephart et al, 2002; Lund and Lephart, 2001a). In contrast, 18 days of exposure to dietary phytoestrogens increased anxiety behavior and stress hormone levels of male rats. Concentrations of genistein or daidzein, which have greater activity at $\operatorname{ER} \beta$ than $E R \alpha$, reduced time spent in social interaction with a conspecific and open arm activity in the plus maze, and significantly elevated stress-induced corticosterone concentrations (Forsling et al, 2003; Hartley et al, 2003). The differences in these findings may reflect the duration and/or concentration of exposure to dietary phytoestrogens and the resulting effects at $\mathrm{ER} \beta$ and/or $\mathrm{ER} \alpha$. Indeed, $\mathrm{E}_{2}$ dosage, duration of exposure, and exposure to stress, are factors that influence whether $\mathrm{E}_{2}$ has antianxiety and/or anxiogenic effects (Walf and Frye, 2005). Using a paradigm analogous to the present experiments, we have shown that $17 \beta-\mathrm{E}_{2}$ and ER $\beta$-selective SERMS reduce depressive behavior (immobility in the forced swim test) compared to $E R \alpha$-selective SERMs or vehicle (Walf $e t$ al, 2004). As further support of the role of $\operatorname{ER} \beta$ in affective behavior, $\operatorname{ER} \beta$ knockout mice have increased anxiety behavior in the elevated plus maze compared to that observed in wild-type mice (Imwalle et al 2005; Krezel et al, 2001) and $\mathrm{ER} \alpha$ knockout mice (Krezel et al, 2001). Thus, the extent to which SERMs activate ER $\beta$, more than $\mathrm{ER} \alpha$, may influence the nature of their effects on affective behavior.

In contrast, $\mathrm{ER} \alpha$ may have a more prominent role in reproduction. Although SERMs with greater activity at $\operatorname{ER} \alpha$, PPT, and $17 \alpha-\mathrm{E}_{2}$, did not alter anxiety behavior, they did facilitate lordosis behavior more than vehicle, and in a manner comparable to $17 \beta-\mathrm{E}_{2}$. These data indicate that PPT and $17 \alpha-\mathrm{E}_{2}$ were available to the brain and could produce specific behavioral effects. ER $\alpha$ has been localized to the hypothalamus, an important brain region for sexual receptivity. $\mathrm{E}_{2}$-facilitated receptivity of rats is blocked by antisense oligonucleotides for $\operatorname{ER} \alpha$ (not $\operatorname{ER} \beta$ ), and does not occur in ER $\beta$ (but does occur in ER $\alpha$ ) knockout mice (Apostolakis et al, 2000; Ogawa et al, 1996, 1998, 1999). Further, ER $\alpha$ knockout mice are anovulatory, have dis- 
rupted luteinizing hormone secretion, and do not respond to trophic actions of $\mathrm{E}_{2}$ on uterine tissues. Although $\mathrm{ER} \alpha$ knockout mice have reduced ovulatory capacity, they are fertile (Hewitt and Korach, 2003). Our data confirm that actions at $\mathrm{ER} \alpha$ are important for lordosis.

$\mathrm{E}_{2}$ also has well known effects on activity and/or arousal of people and animals (Smith, 1994). Proestrous rats or mice, or ovx rats administered $E_{2}$, demonstrate more spontaneous motor activity (Becker et al, 1987; Joyce and Van Hartesveldt, 1984; Morgan and Pfaff, 2002), which may disrupt performance in some behavioral tasks. As well, $\mathrm{E}_{2}$, particularly in the higher range of concentrations $(25 \mu \mathrm{g}$, s.c. to mice), enhances arousal (Morgan and Pfaff, 2002), which may influence performance. In the present experiments, there was some evidence for $\operatorname{ER} \beta$-selective SERMs that had antianxiety effects to also enhance general activity measures in the same tasks, which need to be considered as a possible confound in interpretation of the antianxiety behavioral effects of these compounds. In the open field, $17 \beta-\mathrm{E}_{2}, \mathrm{DPN}$, and coumestrol increased the number of central and peripheral entries. In the elevated plus maze, $17 \beta-\mathrm{E}_{2}$, $\mathrm{DPN}$, and coumestrol, increased time spent on the open arms, decreased time spent on the closed arms, and increased the number of entries to both. In contrast, there were no effects of SERMs on other measures of activity or arousal. SERMs did not alter the number of beam breaks during a 5-min spontaneous activity task, latency to touch the shock-associated prod, or influence flinch/jump responses to shock. Together, these data of SERMs' effects to alter some measures of motor behavior, but not alter latency to touch the shock-associated prod and flinch/jump responses to shock, suggest that the antianxiety effects observed in the present study are influenced, but not solely due to changes in motor activity and/or arousal. Previous research suggests that $\mathrm{E}_{2}$ 's actions at $\mathrm{ER} \alpha$ may be essential for $\mathrm{E}_{2}$-enhanced activity of mice. For example, running wheel activity in $\mathrm{E}_{2}$-primed mice lacking $\mathrm{ER} \alpha$ is attenuated compared to their wild-type controls; however, there are no differences between $\operatorname{ER} \beta$ knockout and their wildtype controls for running wheel activity (Ogawa et al, 2003; Pfaff et al, 2002). These data suggest that further investigation of SERMs' effects on activity and arousal measures are needed to clarify their role in these and other functional effects.

Although the present findings that $\operatorname{ER} \beta$-active SERMs have antianxiety effects are intriguing, the limitations of the findings should be considered. First, the brain areas that mediate $\mathrm{E}_{2}$ 's effects on anxiety have not been established, although the hippocampus, amygdala, and/or septum have been implicated (Frye and Walf, 2002, 2004, 2005; MolinaHernandez and Tellez-Alcantara, 2001). As such, peripheral dosing with SERMs was utilized to characterize the effects of these compounds in the battery of affective tasks utilized in this study. Second, the concentration-dependent and/or time course effects of SERMs were not addressed in the present study. All rats were administered $10 \mu \mathrm{g}$ SERMs $48 \mathrm{~h}$ before testing and plasma or central concentrations of these compounds were not determined. This limitation precludes the conclusion that there is no effect of ER $\alpha$-selective SERMs for affective behavior because the regimen employed may have produced insufficient concentrations of $\mathrm{ER} \alpha$ selective agonists at the time of testing. For example, given the greater distribution of $\operatorname{ER} \beta$ compared to $\mathrm{ER} \alpha$ in the hippocampus (Shughrue et al, 1997), a higher concentration of $E R \alpha$-selective SERMs may be necessary for them to influence anxiety behavior. However, the ER $\alpha$-selective SERM regimen utilized did facilitate lordosis and other reports have demonstrated behavioral effects of lower and higher dosages of both $\operatorname{ER} \alpha$ and $\operatorname{ER} \beta$-selective SERMs (Luine et al, 2003; Overstreet et al, 2004). Perhaps, the ER $\alpha$ selective SERMs utilized in the present study were effective in the hypothalamus, but not limbic regions, to modulate behavioral effects because of the higher density of $\mathrm{ER} \alpha$ in the hypothalamus. Additionally, the potential modulatory role of $\operatorname{ER} \beta$ on $E R \alpha$ is yet another factor that precludes the conclusion that $\mathrm{ER} \alpha$ is not an integral substrate for affective behavior (Lindberg et al, 2003). Third, the specific mechanisms of action for $\mathrm{E}_{2}$ were not clearly identified in these studies. $\mathrm{E}_{2}$ has been shown to alter hypothalamicpituitary-adrenal axis activity, and this may underlie some of the differences observed in affective tasks (Walf and Frye, 2005). It may be that some of the differences, or lack thereof, in the tasks utilized in the present study (ie no differences in latencies to the shock prod or flinch/jump responses and no interactive effects of tamoxifen and SERMs in the light-dark and Vogel tasks) were due to variations in the stress responses of rats. Other laboratories have reported that rats administered DPN have reduced plasma corticosterone levels $30 \mathrm{~min}$ following elevated plus maze testing compared to rats administered $17 \beta-\mathrm{E}_{2}$ and PPT, but not vehicle, administration (Lund et al, 2005). Future experiments could investigate whether $E_{2}$ 's actions via ERs for its effects on anxiety behavior are modulated by activity of the hypothalamic-pituitary-adrenal axis. In support, coadministration of $\mathrm{E}_{2}$ with an $\mathrm{ER}$ antagonist, tamoxifen, attenuates effects of $\mathrm{E}_{2}$ to reduce the adrenocorticotropin hormone and corticosterone response to restraint stress (Young et al, 2001). In the present study, the antianxiety behavior produced by $\operatorname{ER} \beta$-active SERMs was blocked by administration of the nonspecific, but effective, ER antagonist, tamoxifen. Tamoxifen is not a pure ER antagonist and, in some dosages, tamoxifen may exhibit agonist properties, which may be due to actions at $\mathrm{ER} \alpha$, whereas its antagonistic properties may be due to actions at $\operatorname{ER} \beta$ (Watanabe et al, 1997). There was no evidence for nonspecific effects of tamoxifen in the present study. Although the use of a pure ER antagonist, such as ICI 182,780 might be informative, it does not readily cross the blood-brain barrier and must be administered centrally. The purpose of this study was to determine whether effects of peripherally administered SERMs can be attenuated by ER-blockade across all brain regions. In addition, ICI 182,780 may be inactive in the hippocampus $(\mathrm{Gu}$ et al, 1999), as such, this precluded the use of this antagonist. In future experiments, antisense oligonucleotides for $\mathrm{ER} \alpha$ and $\operatorname{ER} \beta$, which block the transcriptional process, and appropriate controls, can be administered directly to putative brain areas. Behavioral effects concomitant with verification of ER blockade will help establish which particular brain regions are critical for $\mathrm{ER} \beta$-mediated antianxiety effects.

The findings that $\operatorname{ER} \beta$-active SERMs produce antianxiety effects have particularly intriguing implications. More women than men suffer from anxiety-related disorders 
(Pigott, 1999; Seeman, 1997; Wittchen and Hoyer, 2001). Some pharmacotherapies for anxiety are addictive and others, such as selective serotonin re-uptake inhibitors, have long-latencies to act and can produce sexual side effects (Lane, 1997). There is evidence that $\mathrm{HT}$ with $\mathrm{E}_{2}$ may have antianxiety effects for some, but not all, women (Arpels, 1996; Campbell and Whitehead, 1977; Pearlstein et al, 1997; Pigott, 1999; Smith et al, 1995; Schmidt et al, 1998; Torizuka et al, 2000). However, a substantial criticism about HTs with $\mathrm{E}_{2}$ are their potential proliferative effects on breast and/or uterine tissues, which are primarily mediated via $\mathrm{ER} \alpha$ (Gustafsson, 2003; Hillisch et al, 2004). Recent reports indicate that administration of $\mathrm{ER} \beta$-selective SERMs, in higher concentrations than were used in the present study, do not demonstrate proliferative effects in uterine tissue of ovx rats (McBride et al, 2004). Together, these data suggest that it may be feasible to dissociate the beneficial antianxiety effects of SERMs from their negative proliferative effects on reproductive organs. Notably, there is evidence that some beneficial effects of SERMs on cognitive performance may require actions at $\mathrm{ER} \alpha$ and/or ER $\beta$ (Lund and Lephart, 2001b; Luine et al, 2003; Rhodes and Frye, 2005); however, this remains to be established.

\section{ACKNOWLEDGEMENTS}

This research was supported by grants from the National Science Foundation (IBN 98-96263; IBN 03-16083) and The University at Albany Summer Research Program. Technical assistance, provided by Chris Acer, Sheena Ballard, Nicole Natasha Frederick, Rebecca Habernig, George Morimoto, Kathleen Prevost, Kanako Sumida, and Seth Wright, is greatly appreciated. The input of Dr Madeline Rhodes on these studies and the resulting manuscript is greatly appreciated.

\section{REFERENCES}

Apostolakis EM, Garai J, Lohmann JE, Clark JH, O’Malley BW (2000). Epidermal growth factor activates reproductive behavior independent of ovarian steroids in female rodents. $\mathrm{Mol}$ Endocrinol 14: 1086-1098.

Arpels JC (1996). The female brain hypoestrogenic continuum from the premenstrual syndrome to menopause. A hypothesis and review of supporting data. J Reprod Med 41: 633-639.

Becker JB, Snyder PJ, Miller MM, Westgate SA, Jenuwine MJ (1987). The influence of estrous cycle and intrastriatal estradiol on sensorimotor performance in the female rat. Pharm Biochem Behav 27: 53-59.

Brocco MJ, Koek W, Degryse AD, Colpaert FC (1990). Comparative studies on the anti-punishment effects of chlordiazepoxide, buspirone and ritanserin in the pigeon, Geller-Seifter and Vogel conflict procedures. Behav Pharmacol 1: 403-418.

Campbell S, Whitehead M (1977). Oestrogen therapy and the menopausal syndrome. Clin Obstet Gynaecol 4: 31-47.

Chaouloff F, Durand M, Mormède P (1997). Anxiety- and activity-related effects of diazepam and chlordiazepoxide in the rat light/dark and dark/light tests. Behav Brain Res 85: $27-35$.
Diaz-Veliz G, Alarcon T, Espinoza C, Dussaubat N, Mora S (1997). Ketanserin and anxiety levels: influence of gender, estrous cycle, ovariectomy and ovarian hormones in female rats. Pharmacol Biochem Behav 58: 637-642.

Etgen AM, Shamamian P (1986). Regulation of estrogen-stimulated lordosis behavior and hypothalamic progestin receptor induction by antiestrogens in female rats. Horm Behav 20: 166-180.

Fernandez-Guasti A, Martinez-Mota L, Estrada-Camarena E, Contreras CM, Lopez-Rubalcava C (1999). Chronic treatment with desipramine induces an estrous cycle-dependent anxiolyticlike action in the burying behavior, but not in the elevated plusmaze test. Pharmacol Biochem Behav 63: 13-20.

Forsling ML, Kallo I, Hartley DE, Heinze L, Ladek R, Coen CW et al (2003). Oestrogen receptor- $\beta$ and neurohypophysial hormones: functional interaction and neuroanatomical localisation. Pharmacol Biochem Behav 76: 535-542.

Frye CA, Bayon LE, Pursnani NK, Purdy RH (1998). The neurosteroids, progesterone and $3 \alpha, 5 \alpha$-THP, enhance sexual motivation, receptivity, and proceptivity in female rats. Brain Res 808: 72-83.

Frye CA, Petralia SM, Rhodes ME (2000). Estrous cycle and sex differences in performance on anxiety tasks coincide with increases in hippocampal progesterone and $3 \alpha, 5 \alpha$-THP. Pharmacol Biochem Behav 67: 587-596.

Frye CA, Walf AA (2002). Changes in progesterone metabolites in the hippocampus can modulate open field and forced swim test behavior of proestrous rats. Horm Behav 41: 306-315.

Frye CA, Walf AA (2004). Estrogen and/or progesterone administered systemically or to the amygdala can have anxiety-, fear-, and pain-reducing effects in ovariectomized rats. Behav Neurosci 118: $306-313$.

Frye CA, Walf AA (2005). Systemic and intra-hippocampal administration of estrogen and/or progesterone to ovariectomized rats has anti-anxiety effects (in progress).

Gu Q, Korach KS, Moss RL (1999). Rapid action of $17 \beta$-estradiol on kainate-induced currents in hippocampal neurons lacking intracellular estrogen receptors. Endocrinol 140: 660-666.

Gustafsson JA (2003). What pharmacologists can learn from recent advances in estrogen signalling. Trends Pharmacol Sci 24: 479-485.

Halbreich U (1997). Role of estrogen in premenopausal depression. Neurology 48: 16-19.

Handa RJ, Reid DL, Resko JA (1986). Androgen receptors in brain and pituitary of female rats: cyclic changes and comparisons with the male. Biol Reprod 34: 293-303.

Handa RJ, Roselli CE, Horton L, Resko JA (1987). The quantitative distribution of cytosolic androgen receptors in microdissected areas of the male rat brain: effects of estrogen treatment. Endocrinology 121: 233-240.

Hardy DF, Debold JF (1971). Effects of mounts without intromission upon the behavior of female rats during the onset of estrogen-induced heat. Physiol Behav 7: 643-645.

Hartley DE, Edwards JE, Spiller CE, Alom N, Tucci S, Seth P et al (2003). The soya isoflavone content of rat diet can increase anxiety and stress hormone release in the male rat. Psychopharmacology 167: 46-53.

Hewitt SC, Korach KS (2003). Oestrogen receptor knockout mice: roles for oestrogen receptors $\alpha$ and $\beta$ in reproductive tissues. Reproduction 125: 143-149.

Hillisch A, Peters O, Kosemund D, Muller G, Walter A, Schneider B et al (2004). Dissecting physiological roles of estrogen receptor $\alpha$ and $\beta$ with potent selective ligands from structure-based design. Mol Endocrinol 18: 1599-1609.

Imwalle DB, Gustafsson JA, Rissman EF (2005). Lack of functional estrogen receptor $\beta$ influences anxiety behavior and serotonin content in female mice. Physiol Behav 84: $157-163$ 
Joyce JN, Van Hartesveldt C (1984). Estradiol application to one striatum produces postural deviation to systemic apomorphine. Pharm Biochem Behav 20: 575-581.

Krezel W, Dupont S, Krust A, Chambon P, Chapman PF (2001). Increased anxiety and synaptic plasticity in estrogen receptor $\beta$ deficient mice. PNAS 98: 12278-12282.

Kuiper GG, Carlsson B, Grandien K, Enmark E, Haggblad J, Nilsson S et al (1997). Comparison of the ligand binding specificity and transcript tissue distribution of estrogen receptors $\alpha$ and $\beta$. Endocrinol 138: 863-870.

Kuiper GG, Lemmen JG, Carlsson B, Corton JC, Safe SH, van der Saag PT et al (1998). Interaction of estrogenic chemicals and phytoestrogens with estrogen receptor $\beta$. Endocrinol 139: 4252-4263.

Lane RM (1997). A critical review of selective serotonin reuptake inhibitor-related sexual dysfunction; incidence, possible aetiology and implications for management. J Psychopharmacol 11: $72-82$.

Lephart ED, West TW, Weber KS, Rhees RW, Setchell KD, Adlercreutz $\mathrm{H}$ et al (2002). Neurobehavioral effects of dietary soy phytoestrogens. Neurotoxicol Teratol 24: 5-16.

Leret ML, Molina-Holgado F, Gonzalez MI (1994). The effect of perinatal exposure to estrogens on the sexually dimorphic response to novelty. Physiol Behav 55: 371-373.

Lindberg MK, Moverare S, Skrtic S, Gao H, Dahlman-Wright K, Gustafsson JA et al (2003). Estrogen receptor (ER)- $\beta$ reduces $\mathrm{ER} \alpha$-regulated gene transcription, supporting a 'ying yang' relationship between $\mathrm{ER} \alpha$ and $\operatorname{ER} \beta$ in mice. Mol Endocrinol 17: 203-208.

Luine VN, Jacome LF, Maclusky NJ (2003). Rapid enhancement of visual and place memory by estrogens in rats. Endocrinology 144: $2836-2844$.

Lund TD, Lephart ED (2001a). Manipulation of prenatal hormones and dietary phytoestrogens during adulthood alter the sexually dimorphic expression of visual spatial memory. BMC Neurosci 2: 21 .

Lund TD, Lephart ED (2001b). Dietary soy phytoestrogens produce anxiolytic effects in the elevated plus-maze. Brain Res 913: 180-184.

Lund TD, Rovis T, Chung WC, Handa RJ (2005). Novel actions of estrogen receptor-beta on anxiety-related behaviors. Endocrino$\log y$ 146: 797-807.

McBride KM, Myracle AB, Ewell ES, Wu T, Faraday MM (2004). Effect of Restraint Stress on Estrogen Receptor (ER) Protein Expression in the Rat Brain Washington, DC: Society for Neuroscience, 2004 Abstract Viewer/Itinerary Planner, Program No. 193.14 (online).

McCarthy MM, Felzenberg E, Robbins A, Pfaff DW, SchwartzGiblin S (1995). Infusions of diazepam and allopregnanolone into the midbrain central gray facilitate open-field behavior and sexual receptivity in female rats. Horm Behav 29: 279-295.

McCarthy MM, McDonald CH, Brooks PJ, Goldman D (1996). An anxiolytic action of oxytocin is enhanced by estrogen in the mouse. Physiol Behav 60: 1209-1215.

Meyers MJ, Sun J, Carlson KE, Marriner GA, Katzenellenbogen BS, Katzenellenbogen JA (2001). Estrogen receptor- $\beta$ potencyselective ligands: structure-activity relationship studies of diarylpropionitriles and their acetylene and polar analogues. J Med Chem 44: 4230-4251.

Molina-Hernandez M, Tellez-Alcantara NP (2001). Estrus variation in anticonflict effects of midazolam microinjected into septal nuclei in female Wistar rats. Pharm Biochem Behav 68: 531-537.

Mora S, Dussaubat N, Diaz-Veliz G (1996). Effects of the estrous cycle and ovarian hormones on behavioral indices of anxiety in female rats. Psychoneuroendocrinology 21: 609-620.

Morgan MA, Pfaff DW (2001). Effects of estrogen on activity and fear-related behaviors in mice. Horm Behav 40: 472-482.
Morgan MA, Pfaff DW (2002). Estrogen's effects on activity, anxiety, and fear in two mouse strains. Behav Brain Res 132: 85-93.

Nomikos GC, Spyraki C (1988). Influence of oestrogen on spontaneous and diazepam-induced exploration of rats in an elevated plus maze. Neuropharmacology 27: 691-696.

Ogawa S, Chan J, Chester AE, Gustafsson JA, Korach KS, Pfaff DW (1999). Survival of reproductive behaviors in estrogen receptor $\beta$ gene-deficient ( $\beta$ ERKO) male and female mice. PNAS 96: 12887-12892.

Ogawa S, Chan J, Gustafsson JA, Korach KS, Pfaff DW (2003). Estrogen increases locomotor activity in mice through estrogen receptor $\alpha$ : specificity for the type of activity. Endocrinology 144 230-239.

Ogawa S, Eng V, Taylor J, Lubahn DB, Korach KS, Pfaff DW (1998). Roles of estrogen receptor- $\alpha$ gene expression in reproduction-related behaviors in female mice. Endocrinology 139: $5070-5081$.

Ogawa S, Taylor JA, Lubahn DB, Korach KS, Pfaff DW (1996). Reversal of sex roles in genetic female mice by disruption of estrogen receptor gene. Neuroendocrinology 64: 467-470.

Overstreet DH, Carlsson R, Dahllund JC, Osterlund MK (2004). Antidepressant- and Anxiolytic-like Effects of Estradiol in Ovariectomized Rats: Strain and Estrogen Receptor Differences Washington, DC: Society for Neuroscience, 2004 Abstract Viewer/Itinerary Planner. Program No. 354.17 (online).

Pearlstein T, Rosen K, Stone AB (1997). Mood disorders and menopause. Endocrinol Metab Clin N Am 26: 279-294.

Pfaff D, Frohlich J, Morgan M (2002). Hormonal and genetic influences on arousal-sexual and otherwise. Trends Neurosci 25: 45-50.

Pigott TA (1999). Gender differences in the epidemiology and treatment of anxiety disorders. J Clin Psychiatry 60: 4-15.

Rhodes ME, Frye CA (2005). ER $\beta$-selective SERMs produce mnemonic-enhancing effects in the inhibitory avoidance and water maze tasks. Neuropsychopharmacology (submitted).

Schmidt PJ, Nieman LK, Danaceau MA, Adams LF, Rubinow DR (1998). Differential behavioral effects of gonadal steroids in women with and in those without premenstrual syndrome. $N$ Engl J Med 338: 209-216.

Seeman MV (1997). Psychopathology in women and men: focus on female hormones. Am J Psychiatry 154: 1641-1647.

Shughrue PJ, Lane MV, Merchenthaler I (1997). Comparative distribution of estrogen receptor- $\alpha$ and $-\beta$ mRNA in the rat central nervous system. J Comp Neurol 388: 507-525.

Smith RN, Studd JW, Zamblera D, Holland EF (1995). A randomised comparison over 8 months of 100 micrograms and 200 micrograms twice weekly doses of transdermal oestradiol in the treatment of severe premenstrual syndrome. $\mathrm{Br} J$ Obstet Gynaecol 102: 475-484.

Smith SS (1994). Female sex steroid hormones: from receptors to networks to performance-actions on the sensorimotor system. Prog Neurobiol 44: 55-86.

Stauffer SR, Coletta CJ, Tedesco R, Nishiguchi G, Carlson K, Sun J et al (2000). Pyrazole ligands: structure-affinity/activity relationships and estrogen receptor- $\alpha$-selective agonists. J Med Chem 43: 4934-4947.

Torizuka K, Mizowaki M, Hanawa T (2000). Menopause and anxiety: focus on steroidal hormones and GABAA receptor. Nippon Yakurigaku Zasshi 115: 21-28.

Walf AA, Frye CA (2005). Estradiol's effects to reduce anxiety and depressive behavior may be mediated by estradiol dose and restraint stress. Neuropsychopharmacology (in revision).

Walf AA, Rhodes ME, Frye CA (2004). Anti-depressant effects of $\operatorname{ER} \beta$ selective estrogen receptor modulators in the forced swim test. Pharm Biochem Behav 78: 523-529. 
Watanabe $\mathrm{T}$, Inoue $\mathrm{S}$, Ogawa $\mathrm{S}$, Ishii $\mathrm{Y}$, Hiroi $\mathrm{H}$, Ikeda $\mathrm{K}$ et al (1997). Agonistic effect of tamoxifen is dependent on cell type, ERE-promoter context, and estrogen receptor subtype: functional difference between estrogen receptors $\alpha$ and $\beta$. Biochem Biophys Res Commun 236: 140-145.
Wittchen HU, Hoyer J (2001). Generalized anxiety disorder: nature and course. J Clin Psychiatry 62: 15-19.

Young EA, Altemus M, Parkison V, Shastry S (2001). Effects of estrogen antagonists and agonists on the ACTH response to restraint stress in female rats. Neuropsychopharmacology 25: 881-891. 